\title{
Analysis of the acceleration of the time on the project showroom Nissan, office and workshop in Pekanbaru city
}

\author{
Tisya Adelia ${ }^{1, *}$ and Hendra Taufik ${ }^{1}$ \\ ${ }^{1}$ Department of Civil Engineering, Universitas Riau, Pekanbaru, Indonesia
}

\begin{abstract}
Completion time determination in project management is among the first and the most important in the process of planning because it can be the basis for the whole planning. Project completion delay result in the elongation of construction time thus it can inflict a costly penalty due to the delays. Project management so important for implementation a project for avoid problem that can create disadvantages for owner or contractor, one of the problems that commonly occur in a project is a estimated cost and timework isn't fit with the planning. Project construction Nissan, Office and Workshop at Pekanbaru City were late from contract duration. Work can more fast with 3 ways, alternative overtime work, alternative add more manpower, and alternative shift system. The analysis conducted focuses on unfinished work. Only work with critical path in analysis. Analysis result obtained cost of construction acceleration that caused by overtime alternative is IDR 15,393,542.00 overtime implemented for 4 hours in a day. Workers additional alternative that adjusted by field requirement result is IDR 25,500,000.00 and shift alternative, construction acceleration that caused by shift alternative is IDR 38,940,000.00. In conclusion, the most effective construction acceleration method is overtime alternative, obtained the minimum financial loss and recommended to use for the construction acceleration.
\end{abstract}

\section{Introduction}

Pekanbaru is one of the cities in Indonesia that has a rapid development of infrastructure in various areas. This will increase economic growth by attracting more investors to invest in various industries in Pekanbaru.

Project can be defined as the activity that took place in a limited time by allocating specific resources and is intended to produce a product or deliverable that the criteria of substandard the outlined clearly. So the more advanced human civilization, increasingly larger, and more complex projects that are done by involving the use of the materials,

${ }^{*}$ Corresponding author: tisyaadelia@gmail.com 
human resources, the advanced technology [1]. The project, in general, has a timeout (deadline) which must be completed before or right at the time that has been in specified. Therefore a project must have good management in planning and managing projects from the beginning of the end of the work so that complete the work following what has been in the plan. But as we know not a little project that has been delayed in the construction, thus required the implementation of project management and correct to avoid and minimize the delay in the project. The implementation of project management is really will bring benefits regarding time and cost if the management was done correctly.

The project reviewed is a development project Showroom Nissan, Office and Workshop in the City of Pekanbaru. PT. Wahana Wirawan Riau Province is the official company showroom Nissan Pekanbaru, which is a group of Indomobil. This showroom is built upon the land area of $\pm 3000 \mathrm{~m}^{2}$. The location of this showroom development project in J1 BCE. Amen Diocese around the showroom development project is indeed still desolate, and there are only a few shop or other buildings, owner select the location for the price of the land in the place is still quite cheap. The location is also close to the terminal going to that allows car marketing Nissan became easier.

Nissan Showroom, Office and Workshop has been delayed on his work in induced by delays in the material until the time of the settlement is not following the time that has been agreed previously. The delay that occurs will affect the costs incurred by contractors. The impact of the delay is very important for the analyzed because of contractors stockpiles unchanged regarding the loss of time and cost. Showroom Nissan, Office, and Workshop are planned to be finished on April 29 $9^{\text {th }}, 2017$, but in the implementation has been delayed until on April 29 $9^{\text {th }}$, 2017, work finished reaching $73.05 \%$, with unfinished work is $26.94 \%$.

Delays in a project can be resolved with how to perform the acceleration of the duration of the project, but of course, this can lead to increase costs. Therefore required an analysis of the acceleration of the project to know how long time can work in quicken and cost that will be issued by contractors. Now the acceleration of the method that can be done is with the addition of work hours (overtime), increase the number of human resources, and equipment and with a shift system.

The purpose of this research is to determine the work in the path of critical and analyzing the acceleration of the project with use three alternative acceleration, the method of adding work hours (overtime), add the human resources and system shift, with determining the acceleration of the alternative based on the most economical cost.

\section{Literature review}

\subsection{Projects}

According to [1], project is a series of activities once the way with the time and resources to achieve the result of that has been determined, for example, the product or production facilities. Where in reaching the result, limited by project budget, schedule, and quality. There are some studies about the acceleration of projects such as in Table 1.

The project is a task that needs to be formulated to achieve the goal stated and must be completed in a certain period with the use of human power with limited tools and so complex that need management and cooperation that is different from normally used [5]. 
Table 1. Previous research.

\begin{tabular}{|c|c|c|c|}
\hline Study & Title & Method & Results \\
\hline$[2]$ & $\begin{array}{c}\text { Analysis of the acceleration } \\
\text { of the time of the project }\end{array}$ & $\begin{array}{c}\text { Add work hours, add manpower } \\
\text { and system shift }\end{array}$ & Overtime method \\
\hline$[3]$ & $\begin{array}{c}\text { Analysis of productivity due } \\
\text { to acceleration }\end{array}$ & $\begin{array}{c}\text { The acceleration of the } \\
\text { implementation of projects in the } \\
\text { time limit specified with 4 } \\
\text { alternative acceleration }\end{array}$ & $\begin{array}{c}\text { The method of } \\
\text { adding } \\
\text { employment with } \\
\text { shift work system }\end{array}$ \\
\hline$[4]$ & $\begin{array}{c}\text { Analysis of the acceleration } \\
\text { of the implementation of the } \\
\text { work of the project on the } \\
\text { development of the road }\end{array}$ & $\begin{array}{c}\text { Add work hours, add manpower } \\
\text { and system shift }\end{array}$ & $\begin{array}{c}\text { Shift system is } \\
\text { more effective }\end{array}$ \\
\hline
\end{tabular}

\subsection{Project management}

Construction projects are increasingly growing fast, therefore in the execution of the project needed a management system that regulates the project from the beginning until the finishing step. Project Management is a science and art related to lead and coordinate resources that consist of man and material using modern management techniques to achieve the goal which has been in specify the scope and the quality of the schedule and cost and satisfy the desire of the stakeholders [1]. Kuzner [6] stated that project management is a business plan, organize, directs, coordinate, and watching activities in the project in such a way work following the schedule and budget which have been planned.

\subsection{Curve S}

Curve $\mathrm{S}$ is the result of Barchart plots aimed to help us to view activities in a period observing the progress of the implementation of the project [7]. The curve $\mathrm{S}$ is a graph drawn up to show the relationship between the increasing value cost or hours who have used or the percentage (\%) solution to the time done. The control of the project, in general, stressed in the control of the schedule. The control of the schedule is done based on the absorption of the cost through the calculation of the curve [8]. Through the curve $\mathrm{S}$ progress of the work that actually can be described and compared with what has been planned. The control of the schedule is done based on the absorption of cost through the calculation of the $\mathrm{S}$ curve. If the graph achievements in field below the graph planning achievement, it is below achievements, if the above said the achievement of faster than the achievement of planning.

\subsection{Critical path}

According to Soeharto [1], a critical path method is a method used to plan and control project. Critical path method is known with the title the critical path. The critical path is a path that has a series of activities with the total amount of time the longest and shows the time frame of the settlement of the fastest project. Critical Path is related to the activity with the longest implementation time. So the critical path is a path that most determine the overall project completion time, drawn with the bold arrow [9]. Yamit [10] stated that the 
usefulness of the critical path is to know the activities that have a very high sensitivity over delays in the completion of the work or also called critical activities. When the activities of delay in the project and will slow down the completion of the project as a whole although other activities do not experience delays.

\subsection{Microsoft project}

Microsoft Project is a program of the computer application used to manage construction projects. The application of project 2013 in the field of construction engineering used to manage the plan or the work of a project that walking can be evaluated following the stages of the work where the system plan on Microsoft Project can help in drawing up the scheduling (scheduling) a project or a series of jobs. Microsoft Project is also able to help make the recording and monitoring of the use of natural resources (resource), both in the form of human resources as well as in the form of equipment.

\subsection{Delays in project}

Levis \& Atherley [11] stated that if a work is targeted to be finished at the appointed time but because of a specific reason could not be fulfilled it can be said that work has been delayed. This will have an impact on the original planning and financial problems. The delay that occurs in a project The construction will extend the duration of the project or increase the cost or both. The impact of the delay in the client or owner is the loss of the opportunity to put its resources into other projects, increase on issued direct costs or increased expenditure for employee salary, rent the equipments, and reduce the benefits.

\subsection{Cause delays in project}

A construction projects many possibilities that can occur so that the result of increased time from an activity or withdrawal time of the completion of the project as a whole. Some possible causes are most often occurs among others: changes the condition of the field, design changes or specification, climate change, in the availability of human resources, materials or equipment.

According to the Soeharto [1] that cause delays in the work on the project can be caused by three things. First, the delay caused by the owner of the error. An error caused by the owner of a project include the reason for the provision of the land, make changes, the reason for the late installment payment to contractors, and the owner of the assign another contractor to do the job. Second, the delay caused by contractor error.

An error caused by the contractor includes late start work, the supervisors from the implementation in the field are less active, too late to bring the equipment, and planning the work less good. Third, the delay is not an error project owner or contractor. The errors include the existence of natural factors, for example, the earthquake, flood, and others, economic changes from the government in a region, the fire on the location of the work, and the existence of the war. 


\subsection{Impact on delays}

The delay will have an impact on the original planning and financial problems. The delay in construction of the project will extend the duration of the project or increase the cost or both. Now the impact of the delay on the owner is a potential loss of income from the facility constructed does not match the specified time, while on the contractor is the loss of the opportunity to put its resources into other projects, increasing cost not directly (indirect cost) by increasing the expenditure for employee salary and rent the equipment and reduce the benefits [11]. Delays in a project for the same contractor with overhead costs rise by increasing the length of time the implementation of. So the contractors will suffer loss due to the possibility of rising prices as a result of inflation and rising wages on.

\subsection{Method of shortening the duration}

Shortening the duration can be done with the terms as follows:

1. Done on the critical line activities

2. The amount of shortening the duration of which was held following the duration of time needed to resolve the delay.

The formula of the shortening of the duration of the method with the addition of work hours (overtime) each activity [12] as the formula.

$$
\gamma=\left\{\left(D_{1} \cdot t_{1}\right) \cdot T_{1}\left(B_{m^{+}}\left(U_{p j} f_{1}\right)\right)\right\}\left\{\left(D_{a}-D_{c}\right)\left(T U_{p h}\right)\right\}
$$

The Eq. 2 for the additional cost of equipment that overtime:

$$
\gamma=\left\{\left(D_{1} \cdot t_{1}\right)\left(P+B_{p j}\right)\right\} \quad\left\{\left(\begin{array}{ll}
D_{\bar{a}} & D_{c}
\end{array}\right)\left(\begin{array}{ll}
F & B_{p h}
\end{array}\right)\right\}
$$

The formula to shorten duration with the addition of manpower as in Eq. 3:

$$
\gamma=\left\{\left(D_{c} \cdot T_{b}\right)\left(\begin{array}{ll}
U_{p h} & B_{t_{h}}
\end{array}\right)\left(B_{t} T_{b}\right)\right\} \quad\left\{\left(\begin{array}{ll}
D_{\bar{a}} & D_{c}
\end{array}\right)\left(U_{\dot{p h}} T\right)\right\}
$$

Eq. 4 related to activities using the equipment, additional cost formula:

$$
\gamma=\left\{D_{e}\left(D_{c} \cdot B_{p h}\right)\left(P_{b}+T_{r}\right)\right\} \quad\left\{\left(\bigoplus_{a} D_{c} \cdot\right)\left(\begin{array}{ll}
P & B_{p h}
\end{array}\right)\right\}
$$

The formula of adding the cost with each shift work activities as in Eq. 5:

$$
\gamma=\left\{\left(D_{c} \cdot T_{b}\right)\left(\begin{array}{ll}
U_{t_{p h}} & B_{t_{n}}
\end{array}\right)\left(\begin{array}{ll}
B_{t} & T_{b}
\end{array}\right)\right\} \quad\left\{\left(\begin{array}{ll}
D_{\bar{a}} & D_{c}
\end{array}\right)\left(\begin{array}{ll}
U_{\dot{p h}} & T
\end{array}\right)\right\}
$$

The Eq. 6 for activities using the equipment for additional cost follows:

$$
\gamma=\left\{D_{e}\left(P \cdot P_{S S}\right)\left(\begin{array}{ll}
W_{s} & B_{p j}
\end{array}\right)\right\}\left\{\left(D_{a}-D_{c}\right)\left(P \cdot B_{p h}\right)\right\}
$$

where $B_{m}=$ Cost of food workers overtime each day (IDR/day), $B_{p h}=$ Cost of ownership per day (IDR), $B_{p j}=$ Cost of ownership per hour (IDR), $B_{t}=$ Cost of transportation for adding worker each person (IDR), $D_{a}=$ Duration of the initial plan (days), $D_{c}=$ Duration after the shortening (days), $D_{l}=$ Ever overtime (hours/week), $f_{l}=$ Multiplication factor overtime pay, $P=$ Number of equipment (of/day), $P_{b}=$ Number of additional equipment (people), $P_{S S}=$ Number of shift equipment day (unit), $P_{s m}=$ Number of night shift equipment (unit), $t_{1}=$ Addition time overtime (hours/week), $T=$ Number of workers per 
day (people/day), $T_{r}=$ Mobilisation costs per unit (IDR/day), $T_{S S}=$ Manpower shift work day (people), $T_{s m}=$ Manpower night shift work (people), $U_{p j}=$ Wages of workers per hour (IDR/day), $U_{p h}=$ Wages of workers per day (IDR/day), $W_{S S}=$ Long shift day (hours), $\mathrm{W}_{\mathrm{sm}}$ $=$ Long night shift (hours), $Y=$ Additional cost.

\section{Methodology}

This research was done on the project of development of our showroom Nissan, Office and Workshop in the City of Pekanbaru. Research method this last task is divided into three parts of data collection, data processing and get the output that will be analyzed.

This research as a whole using the secondary data obtained from data on the development of our showroom Nissan, Office and Workshop in the City of Pekanbaru.

The data collected in this study include secondary data. Secondary data is datasupporting data that can be made and reference input used in analyzing delays and acceleration. Secondary data can be data scheduling and the curve S daily report work project contracts. The data to know the scale of the cost of acceleration with the help of the program Microsoft Excel 2016 and Microsoft Project 2013.

\section{Results and discussion}

Table 2. Work structure that experience critical path.

\begin{tabular}{|c|c|}
\hline Job description & $\begin{array}{c}\text { The duration of work } \\
\text { (days) }\end{array}$ \\
\hline Composite concrete column floor 1 & 2 \\
\hline Composite concrete column floor 2 & 3 \\
\hline Composite concrete column floor 3 & 5 \\
\hline Water proofing toiletvfloor 2 \& 3 + ablution site & 10 \\
\hline Water proofing dak floor parking 3 & 3 \\
\hline The dak waterproofing roof & 6 \\
\hline Waterproofing ramp up & 2 \\
\hline Entrance + bordes waterproofing & 2 \\
\hline Open channel 3x10 parked roof \& ramp & \\
\hline
\end{tabular}

The weekly report is a report that describes the progress of the project every week. Nissan Showroom Development Project, Office, and Workshop in Pekanbaru has experienced delays. The work that has been analyzed is the work which has not been finished $100 \%$, from the results of the analyzes carried out not all the work experience critical path, now the activities that experienced a critical path can be seen in Table 2. The work that is located in the path of critical analysis using 3 alternative. The results of the analysis shortening the duration of the third alternative can be seen in the Table 3 .

Analysis of the recapitulation of the manpower costs for each alternative: 
1. Alternative I. Overtime Method. Based on the analysis results using Microsoft Office Project 2013 Alternative 2013 overtime to complete the work that is in a critical path for 35 days from the initial duration during 84 days. For the acceleration of the alternative overtime done during 35 days with additional cost IDR 15,393,542.00.

2. Alternative II. Adding manpower Method. Based on the analysis results using Microsoft Office Project 2013 alternative adding of manpower can complete the work that is in a critical path for 26 days from the initial duration during 84 days. For the acceleration of the alternative addition of manpower done for 26 days with additional cost IDR 25,500,000.00.

3. Alternative III. System Shift Method. Based on the analysis results using Microsoft Office Project 2013 alternative system shift can complete the work in a critical path for 30 days from the initial duration during 84 days. For the acceleration of the shift work done alternative 30 days with additional cost IDR 38,940,000.00.

Table 3. Recapitulation after shortening the duration.

\begin{tabular}{|c|c|c|c|c|}
\hline \multirow[b]{2}{*}{ Job description } & \multirow{2}{*}{$\begin{array}{l}\text { Duration of } \\
\text { the } \\
\text { beginning } \\
\text { (days) }\end{array}$} & \multicolumn{3}{|c|}{ Duration after the shortening (days) } \\
\hline & & $\begin{array}{l}\text { Over time } \\
\text { method }\end{array}$ & $\begin{array}{l}\text { Adding } \\
\text { manpower } \\
\text { method }\end{array}$ & $\begin{array}{l}\text { System shift } \\
\text { method }\end{array}$ \\
\hline $\begin{array}{l}\text { Composite concrete } \\
\text { column floor } 1\end{array}$ & 6 & 5 & 3 & 4 \\
\hline $\begin{array}{l}\text { Composite concrete } \\
\text { column floor } 1\end{array}$ & 6 & 5 & 3 & 4 \\
\hline $\begin{array}{l}\text { Composite concrete } \\
\text { column floor } 2\end{array}$ & 6 & 5 & 3 & 4 \\
\hline $\begin{array}{l}\text { Composite concrete } \\
\text { column floor } 3\end{array}$ & 6 & 5 & 3 & 4 \\
\hline $\begin{array}{l}\text { Water proofing toilet } \\
\text { floor } 2 \& 3+\text { ablution } \\
\text { site }\end{array}$ & 6 & 5 & 3 & 4 \\
\hline $\begin{array}{l}\text { Water proofing dak } \\
\text { floor parking } 3\end{array}$ & 5 & 4 & 2 & 3 \\
\hline $\begin{array}{l}\text { Water proofing dak } \\
\text { roof }\end{array}$ & 5 & 4 & 2 & 3 \\
\hline Waterproofing ramp up & 5 & 4 & 2 & 3 \\
\hline $\begin{array}{l}\text { Water proofing } \\
\text { entrance }+ \text { bordes }\end{array}$ & 4 & 3 & 2 & 3 \\
\hline $\begin{array}{l}\text { Open channel } 3 \times 10 \\
\text { parked roof \& ramp }\end{array}$ & 5 & 4 & 3 & 3 \\
\hline
\end{tabular}

Analysis of shortening the duration is done by looking at some of the things in each method used. The method of adding work hours (overtime) must pay attention to the productivity of the workers who continue to decline caused by fatigue in work. The method of adding manpower must also consider the number of workers in the add must be following the requirements of each job that is in the field not to happen the accumulation of 
the workers in the field. So also with the system shift method where this method is the same with the method over time, but the productivity of the workers on the night of the 80 percent of workers day. Also, the number of workers who work on the day shift and night shift must be numbered the same.

Based on the explanation above the alternative I, adding working hours (overtime) method is an alternative with the longest duration when we compared with the other two methods. Because in overtime method there is a decrease in productivity cause tired of working all day. But if we are looking regarding cost, overtime method is the most economical alternative with additional cost IDR 15,393,542.00 with time work 35 days.

\section{Conclusions}

The structure of the work experience critical path namely composite concrete column floor 1 , composite concrete column floor 2, composite concrete column floor 3 , waterproofing toilet floor $2 \& 3+$ ablution space, waterproofing dak floor parking 3 , the dak waterproofing roof, waterproofing ramp up, bordes waterproofing entrance stairs and open channel $3 \times 10$ in parking roof \& ramp. The most economical alternative to the acceleration of three alternatives that has been analyzed is an alternative over time. The duration of the normal is 84 days and can become 35 days with the cost of acceleration that IDR $15,393,542.00$.

\section{References}

1. I. Soeharto, Project management (from conceptual to operational) (Erlangga, Jakarta, 1999)

2. A. Pratama, Analysis of the acceleration of the time (Project case study: SKPD Office Building B3 in Tenayan) (Univ. Riau, Pekanbaru 2016)

3. Y. Rasyid, Analisa percepatan produktivitas akibat CCO, studi kasus apron bandara SSK II Pekanbaru (Undergraduate Thesis, Universitas Riau, Pekanbaru, 2015)

4. T. Adipa, Analisis percepatan pelaksanaan pekerjaan pada proyek pembangunan jalan Simpang Petai-Sari Galuh Kecamatan Rumbio Jaya Kabupaten Kampar (Undergraduate Thesis, Universitas Riau, Pekanbaru, 2015)

5. A.A. Karaini, Introduction to project management (Univ. Gunadarma, Jakarta, 2002)

6. H. Kerzner, Project management, A system to planning, scheduling, and Controlling (Van Nostrand Reinbold, New York, 1995)

7. M. Callahan, Construction project scheduling (McGraw Hill, New York, 1992)

8. R. Amelia, Alternative to reduce the impact of the delay of the project on time and cost (Univ. Riau, Pekanbaru 2009)

9. Badri, Dasar-dasar network planning (Rineka, Jakarta, 1997)

10. Yamit, Project management (Graha Knowledge, Yogyakarta, 2000)

11. Levis, Atherley. Delay construction (Langford, New York, 1996)

12. Sadjana. The study of delay in the project on increased costs contractor (ITB, Bandung (1995) 